\title{
Soviet Art Movements between 1917-1990
}

\section{Leyla Onen}

Department of Painting and Printing Arts Department, Gorele Fine Arts Faculty, Giresun University, Giresun, Turkey

Email: ressam_aliyeva@windowslive.com

How to cite this paper: Onen, L. (2021). Soviet Art Movements between 1917-1990. Art and Design Review, 9, 131-147. https://doi.org/10.4236/adr.2021.92012

Received: February 8, 2021

Accepted: April 16, 2021

Published: April 19, 2021

Copyright $\odot 2021$ by author(s) and Scientific Research Publishing Inc. This work is licensed under the Creative Commons Attribution International License (CC BY 4.0).

http://creativecommons.org/licenses/by/4.0/

\begin{abstract}
After the October revolution of 1917, the Soviet Union was established by uniting five countries under one roof. After the Soviet Union was established, with the proposal of the totalitarian regime, the understanding of Social realism was accepted as the dominant view in all areas. In this study, the works produced by the artists of the Soviet Union in the style of Social realism were examined and the works produced in different years were examined. At the same time, the works produced in the style of Constructivism, Suprematism, Social Realism, Hard realism, New realism that emerged in Soviet art were also included in the study. This study was created by qualitative research method. In the study, works in the style of Constructivism, Suprematism, Hard realism, Neorealism and works that are used as propaganda tools and produced with the tendency to rule the society are examined. Examining the works produced in various styles in the Soviet Union revealed the importance of the research. In the study, it is aimed to examine the artist and their works between the years 1917-1990 with the method of artistic criticism.
\end{abstract}

\section{Keywords}

Soviet Art, Social Realism, Suprematism, Hard Realism, Constructivism

\section{Introduction}

The march initiated by working-class women in Russia in 1917 demanding a reduction in the work-hour burden affected the whole country. Lenin and Trotsky seized power, using the situation to their advantage.

Vladimir Ilich Lenin was born on April 22, 1870 in the Ulyanov's province of Russia in an educated and enlightened family. Influenced by the execution of his brother by the tsarist government, he put forward the theory of Leninism through his Marxist ideas against the regime. In Leon Trotsky, Markst, like Lenin, put forward the ideas of Trotskyism and was appointed to the People's Commissariat for War (Köktürk, 2017: p. 61). The General Secretary of the 
Communist Party of the Soviet Union, Josef Stalin and the Chinese revolutionary Mao Zedon opposed the theories. In 1922, Trotsky lost the power struggle against Stalin. At the Second Congress of the Democratic Labor Party in 1903, the Bolshevik (majority) and Menshevik (minority) groups emerged as the supporters of Lenin and the supporters of Martov. Supporters of Lenin constituted the majority. The revolution that took place with the victory of the Bolsheviks in 1917 went down in history as the October revolution (Hudaynazarov, 2003: pp. 7-9). After the October revolution, an attack was launched against any danger from neighboring states. After the attack launched on the pretext of danger, nations of various ethnic and cultural values united under the umbrella of the Union of Soviet Socialist Republics (USSR) (Efendi, 2007: p. 248).

\section{Method}

This study was created by qualitative research method. In the study, the works produced in the style of Constructivism, Suprematism, Social Realism, Hard realism, Neorealism that emerged in the Soviet period are included and analyzed. At the same time, works in which Socialism, the dominant view, took place as a propaganda tool were also discussed. Including various styles together with Social realism in the research reveals the importance. The aim of the study is to examine the artist and their works in the Soviet Union.

\section{The Emergence of Social Realism}

The October revolution that took place in 1917 showed its influence in many fields, including art. The Communist Party published a declaration containing views on literature and politics on June 18, 1925. Views supporting the bourgeoisie are also included in the declaration, which contains information on the lifestyle of the countries of the Soviet Socialist Republics. Following the declaration, the Socialist ideology was supported in both art and social life fields. Opposing special rights to the elite, the working class issued a declaration defending equal rights in all spheres of artistic, cultural and social life (Cebrailoğlu, 2005: p. 60).

In May 1932, the Social Realism understanding emerged in the Soviet Union Party Congress in order to approve the view of the government and instill it into the society. This term, which was first used by the Russian writer Maxim Gorky (1868-1936), was included in the novel "Mother", which he put forward in 1906-07. Social Realism supports the general mindset of this novel (Tağızade, 2006: p. 9).

Soviet writer Ivan Mikhaylovich Gronsky wrote an article on Social Realism in a newspaper and introduced it to the world. In 1934, the Central Committee officially declared the Socialist Realism understanding as the artistic practice of the USSR. Based on the idea of "art is for society" with Social Realism, an artistic policy that aims to produce artistic works and develop. In the Second Writers' Congress in 1934, it was decided that the understanding of Social Realism should be the dominant view in all fields (Hacıyev \& Dadaşzade, 1969: p. 21). 
The understanding of Social Realism was based on the Marxist philosophical understanding, its aesthetic and literary origin on Russian literature, and its political Bolshevik movement. Social Realism originated on the aesthetic theory of the Russian philosopher, writer and critic Nikolay Chernyshevsky (1828-1889), which relates to his view of art. According to Tağızade (2006), in his doctoral dissertation titled "The aesthetic approach of art to the real", Chernyshevsky was defending the view that life and nature itself are beautiful and the understanding of fine sense of the Marxist ideology.

As a result of the decisions taken in this period, it has become necessary and force majeure to produce works on the understanding of Social Realism. With the management policies of the Soviet Union, works with propaganda character emerged. The artists tried to reveal the positive feeling of enthusiasm in the society with the works they produced in the style of Social Realism. Based on this understanding, many steps have been taken to ensure that "Art is for society" is the dominant view in all segments of society. The idea of dealing with the daily life and difficulties of society constitutes the basis of Social Realism. However, Soviet painters produced works that could be perceived by all segments of society in line with the repressive policies of the government (Aliyev, 2007: p. 9).

According to Şimşek (2007), works that include the understanding of Social Realism treat the oppressed as an art object and contribute to the education levels of the working class and peasants. It took place to put forward class struggles in the "responsibility" of art. Social Realism introduced by the Soviet Union supported the development of the state by penetrating all segments of society. Artists Social Realism has begun to produce works that glorify workers, toiling heroes who serve. With the new regulations made in the field of art after Stalin's domination, the production of works that do not include the understanding of Social Realism was prohibited, and it was asked to produce works that praised the regime. After 1932, works such as novels, poems, films, paintings and sculptures began to be produced in order to instill the Soviet spirit in the society. Emotions such as happiness and positivity were tried to be reflected in the pictures by using vibrant and pastel colors. Steps have been taken aimed at the development of Social Realism. One of the main aims of socialist reality is to achieve integrity in the changes that occur in society's ideas and thoughts (Efendiyeva, 2010: p. 340).

With the application of the idea of Social Realism in art, art has been taken over by the power and started to be used as a propaganda tool. In order for the concept of socialism to be accepted and adopted by the society, an education system supporting the concept was created. Socialism has become the only movement in the Soviet Union by penetrating all fields, including art education, and its education has been made force majeure (Uygur, 2005: p. 6).

According to Lenin, it is necessary to produce works suitable for the purpose of the people through art. Lenin argued that art belongs to the people and must serve the working class. Art development should be provided by revealing the 
feelings and thoughts of the people. Art propaganda, which was created based on these thoughts, has been instrumental in achieving unity and solidarity in the society as in the "one heart, one fist" understanding. For example, the cooperation of the state and society in the agricultural field has led to developments. With this, the Soviet Union developed economically and gained power. This situation has positively affected the artists economically. Artists devoted their time to their arts by receiving many supports such as artistic material, home, monthly income as state support (Efendi, 2007: p. 255).

Tağızade (2006: p. 8) stated in her research that the Soviet government used art as a means of disseminating ideology and this situation became common in totalitarian regimes and turned into theory. In the Soviet period, the prohibition of production outside the framework of the understanding of Socialism caused the prohibition of works that were used as means of expression. Thus, painting artists were obliged to make works with the understanding of Socialism (Bozdağ, 2015: p. 113).

The shaping of society with the support of socialist international organizations has led to changes in art, literature and politics. The understanding of Socialist Realism, which takes place in every field of science and art in its own way, has become the dominant understanding in all segments of society (Roy, 2000: p. 120).

Socialism, which was the dominant understanding in all fields in the Soviet Union, was also dominant in art education. After 1932, with the reforms of the Soviet Union in art education, academic style paintings that praised the regime and based on social realism began to be produced (Patterson, 1999). At the same time, the production of works that convey traditional values was prohibited in Soviet art with the pressure of the administration and artists were obliged to produce works with the understanding of Social Realism (Sabancall, 2006: p. 22).

According to Uygur (2005: p. 6), it was thought that "significant progress would be made in the realization of the Second Renaissance" by the Soviet government in the field of art. Soviet art developed based on the rules of Socialism to create a Soviet man. This was among the aims of Soviet art. After socialism became the dominant understanding in Soviet art, artworks that glorified government officials and chieftains were produced by artists. Isaac Brodsky's various portraits of Lenin (1918) and Stalin (1930), Fyodor Reshetnikov Stalin (1941), and the works of artist Gerasimov Lenin in the tribune (1929-30) are the obvious examples of this. Works that praised and preached the proletariat, starting from the 1930s, had an important place in Soviet art. In the years when the understanding of socialism was dominant, works on landscapes, still life and historical subjects were included in Soviet painting together with the portrait type. Soviet artists conveyed the beauty of their country in landscape painting. The daily life of the working class and peasant class in Soviet art was reflected in the works enthusiastically. The characters in the works are depicted in vivid colors and conveyed in a happy and cheerful manner. In the works, it is tried to show that the society is moving towards a bright future in a carefree and happy 
way. In Soviet art, issues based on oil, industrialization and urbanization were dominant, along with the glorification of the workers and toilers, heroes and those in power. At the same time, works of praise for the regime were produced. In the works produced during and after the Second World War, subjects such as war, peace and victory were included. However, Soviet artists have shown that they support the government, the power, by producing many works with revolutionary content (Barut, Odacıoğlu, Köktürk, 2016: p. 465).

\section{Soviet Art}

When it comes to Soviet art, the first thing that comes to mind is the art of Socialism. Socialism has had an important place in the Soviet Union since the early 1930s. Until 1930, many revolutionary and innovative works were produced in Soviet art. With this, new art movements emerged in Soviet art. With the dominance of social realism, it has led to the monotonous development of art. In the Soviet Union, new artistic movements emerged from the 1960s and began to produce works with a new style of expression. New approaches in art have been seen in the last years of the association. In this section, the styles, artists and works that emerged in different periods of the Soviet Union are included.

\subsection{Suprematism}

With the establishment of the Soviet Union, a new era has entered in the cultural, social and artistic fields of the countries involved. Art produced in the Soviet Union was often put forward to support change, development, new ideas, revolution, and the Bolsheviks. In 1913, Kazimir Malevich (1878-1935) introduced the revolutionary art movement that supported innovative ideas in Russia. This movement, known as Suprematism, consisted of works containing plain color and geometric forms.

Kazimir Malevich was born in Kiev, the capital of Ukraine, in 1878. He received his education at the Moscow State School of Painting, Sculpture and Architecture. According to Malevich, avant-garde arts before Suprematism were not consistent and deterministic enough (Иньшаков, 2018: p. 183). Until the advent of Suprematism, he produced works in the style of Cubism. Supermatism is considered as abstract art consisting of geometric elements such as square, rectangle, and round in a contrasting color background (Avşar Karabaş \& Damar, 2016: p. 103). The artist's work named Black Square took place in the exhibition named "0 - 10" (Figure 1). This work, which made a great impact in the exhibition held in 1919, was removed from the subject. Black Square has been accepted as the last point of painting. Consisting of a black square on a white background, the work draws attention with its simplicity. He used free forms in Malevich's works created with an expressive character (Uyanık, 2012: p. 109).

\subsection{Constructivism}

Vladimir Tatlin was among the artists who supported the development of art for 


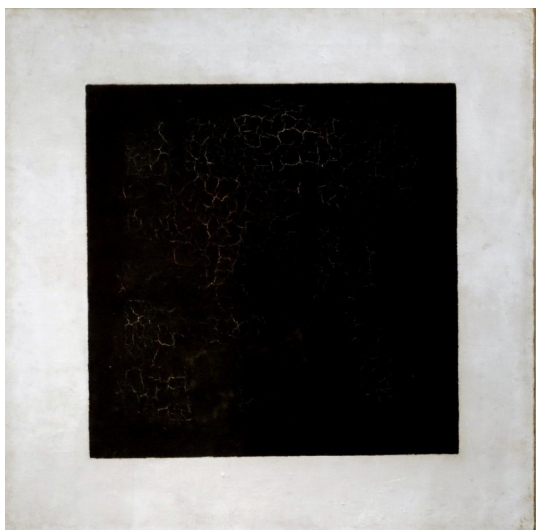

Figure 1. Kazimir Malevich, Black Square, $80 \times 80$. 1913-1915.

the purposes of the October revolution in the early period of the Soviet Union. According to Antmen (2010: p. 105) Tatlin is considered the founder of Russian Constructivism. Constructivism that emerged in Russia in 1913 has spread in Europe since the middle of the $20^{\text {th }}$ century. This art movement occurs in works that use "contemporary materials and have a geometric composition" (Sözen, 2001: p. 40) structure. Geometric and experimental works took place in the constructivism movement. It contains a universal meaning in terms of the understanding of the development of life on a new plane. Members of the constructivist movement defended peace against the Second World War. The subject of this movement is laconic and "very minimal, which has created a systematic art style" (Çöklü, 2014: p. 1). Constructivism, by opposing academic and realism teachings in art and rejecting traditional arts, preferred to produce works that would direct science with the characteristics of industrialization. Antoine Pevsner, Kazimir Malevich, El Lissitzky, Naum Gabo and Wassily Kandinsky were among the members of this movement, which remained active in the Soviet Union until 1922 (Bannister, 2012: p. 1).

Tatlin, an architect and painting artist, is known for his innovative views and experimental works. Tatlin accepted figurative art as traditional and suggested that works be done in mathematical form (Пунин, 1994: p. 15). Tatlin was born in 1985 in Moscow, the capital of Russia. He received his art education at Penza Vocational School of Fine Arts in Moscow. Tatlin made his name as an artist with his work titled Tatlin's Tower, which he exhibited in the " 0,10 " exhibition (Figure 2). This work also reminds us of the destroyed "Hanging Gardens" of Babylon. The technical length of this tower is four hundred meters and it is made in a spiral. It stretches tapering upwards like a round staircase. Glass and metal were used in the construction of this tower, which consists of geometric elements. Tatlin's Tower is a building for propaganda, it is active, it is intended to host cultural programs, political propaganda and tools (Çolak, 2020: abst).

Lazar Markovich El Lissitzky, one of the members of Constructivism, was born in 1890 in the province of Pochinyok in Russia. He graduated from Latvia Polytechnic University as an architect. The artist has works in the fields of architecture, painting, graphics and design. The artist of Jewish origin worked as 
an educator at the Belorussia National Vocational School of Fine Arts between 1919 and 1920 upon the proposal of the artist Mark Chagall. In 1920, influenced by Kazimir Malevich, he produced works in the style of Suprematism (ХанМагомедов, 1975). Lissitzky, with his expression bearing the traces of symbolism in monochrome and empty spaces, "attributed meanings to the geometric elements he uses in his design concept and conveyed the message to the audience" (Uyanık, 2012: p. 115). At the same time, he included geometric elements such as square, circle and the element of balance in his works. The work was made in 1920, in the Lenin Tribune, has a propaganda character in favor of the Soviet Union (Figure 3). According to Мордвинова (2017: p. 143), this work has been created in a very plain style. Application of new techniques in Soviet Union art it slowed down with the start of the Second World War.

Constructivist artist Gustav Klutsis was born in 1985 in Latvia. Klutsis produced works based on the propaganda understanding of Social Realism and Constructivism techniques. Klutsis preferred to glorify the laborer and the working class with his works he produced using photomontage technique. He

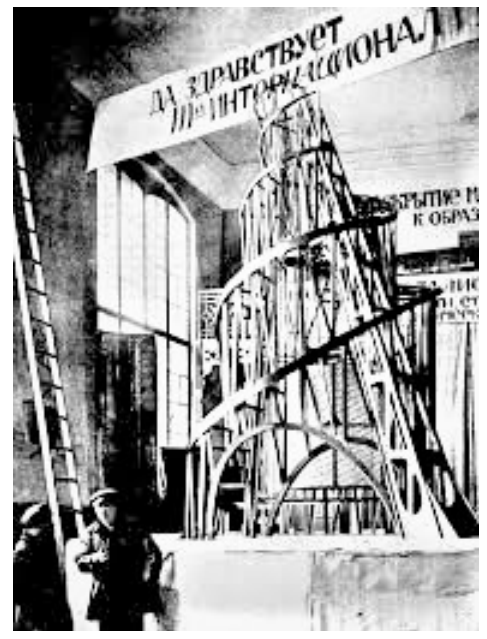

Figure 2. Vladimir Tatlin, Tatlin’s Tower, 400 meters, metal, glass, 1919.

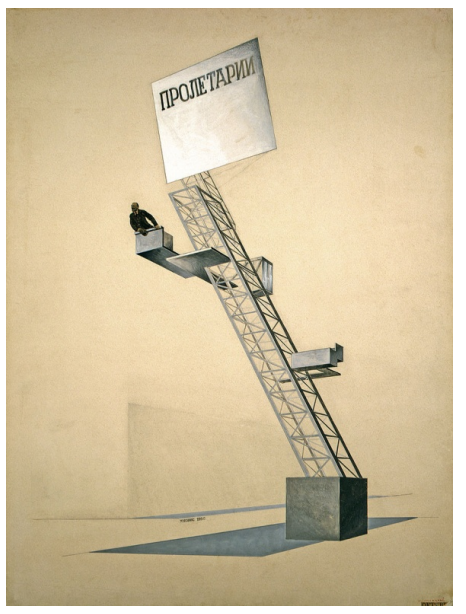

Figure 3. El Lissitzky, in the Lenin Tribune, Paper, 1920. 
mainly used red and black colors in his works. His works have a lively and simple narrative language. One of his works with a revolutionary character is his work in 1936, the flags of Marks, Engels, Lenin and Stalin up (Figure 4). In this work, there are portraits of Marx, Engels, Lenin and Stalin, respectively, in gray and black on red. At the top of the work; Flags fly over the portraits of Marx, Engels, Lenin and Stalin. In these flags, he conveyed the industrialization process of the Soviet Union and the development in the field of agriculture. In the lower part of the work, he depicts the October revolution, the establishment of the Soviet Union and the crowd of all walks of life. At the bottom of the work, the flags of Marx, Engels, Lenin and Stalin up! In red letters is written (Uyanik, 2012: p. 35).

Until the 1930s, artists such as Anton Chekhov, Fyodor Dostoyevsky, Lev Tolstoy, Solzhenitsky, Maxim Gorky, Pyotr Tchaikovsky, Fyodor Shalyapin in the field of music and Mark Chagall, El Lissitzky, Wassily Kandinsky, Vladimir Tatlin, Kazimir Malevich and has pioneered changes and developments with innovative views in the artistic field. Many of these artists could not cope with the pressure of the regime and continued their art abroad.

\subsection{Social Realism}

Since the 1930s, with Stalin's attempt under the rule of the Soviet Union, the political view of respect for identity and glorification of rulers has shown its effect in the field of art. Since 1934, Social Realism has been officially recognized as the only trend in Soviet art. Artistic, social and cultural areas were now under the control of the party and the state. With the pressure of the totalitarian regime, the artists fulfilled the task of guiding the daily life of the society by describing the daily life of the society in a happy enthusiastic way through art. Based on this understanding, the artists reflected positive emotions and conveyed cheerful and hardworking characters. Workers, revolutionaries are exalted and heroized and symbolized. With this policy of encouragement, all segments of the society were tried to be directed towards socialism (Uygur, 2005: p. 6). Many painters such as Yoganson, Gerasimov, Pimenov, Korin, Konchalovsky, Vodkin, Mikayıl Abdullayev, Tagı Tagiyev, Trivagonov, Nesterov, Reshetnikov, Brodsky, Bozkov, Popkov took part in Soviet art with their works reflecting the style of Social Realism. The artists reflected the daily life of the society in their works and conveyed strong and

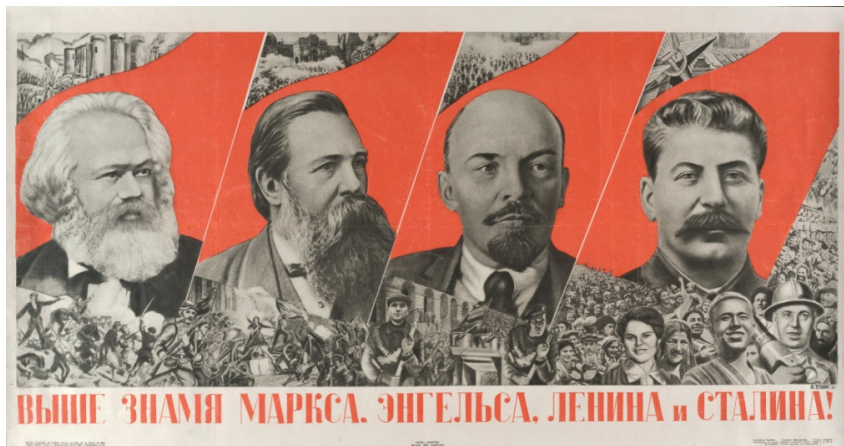

Figure 4. Flags of Gustav Klutsist, the flags of Marks, Engels, Lenin and Stalin up!, 1936. 
hardworking people with satisfaction. Works in the style of Socialist Realism that will be understood by all parts of the society and that provided development in Soviet art were produced (Kenez, 2003: p. 446).

Yuri Pimenov is one of the artists who produced works with the understanding of Socialism. Yuri Ivanovich Pimenov was born in 1903 in Moskow. Between 1920 and 1925, he studied Russian State Art and Technical School. He founded the society of Easel Painters. Like the artist Yoganson, Yuri also produced works in the classical Social Realism style. The artist reflected a part of daily life in his works. Pimenov included genres such as portrait, still life and figurative composition in his works. Feelings of happiness and enthusiasm are felt in his works. In his works that he produced in the 1920s and 1930s, the artist supported the development in artistic, cultural and industrial fields and included the subjects of labor and heroism (Лаптева, 2013: p. 7). These features are seen in the artist's work titled "Let there be heavy industry" (Figure 5). In this work done in 1927, the working class and the working class are depicted. Workers are working diligently in the foreground of the work. The faces and bodies of some workers in the work are black. He tried to show the difficulty of this job. Tankers with oil reserves are depicted in the background. The development of the industry was conveyed by freight trains located here. However, we can see that there is reference to industrialization. When we examine the work carefully, we can see the electric poles in the middle. The artist drew attention to the economic role of the working class in the development of the Soviet Union by working courageously. With this work, the working class has been glorified and conveyed as the heroes of society.

According to Aliyeva Önen (2019), "The first thing that comes to mind when art is mentioned in the Soviet Union is the understanding of Social Realism". In Social Realism, portraits were first put forward to glorify Lenin. The artist who created works based on Social Realism is Alexandr Mikhailovich Gerasimov. Gerasimov, was born in 1881 in Michurinsk, Russia. Aleksandr Gerasimov produced his work "Lenin in Tribune" (Figure 6). In the work produced in 1929-30,

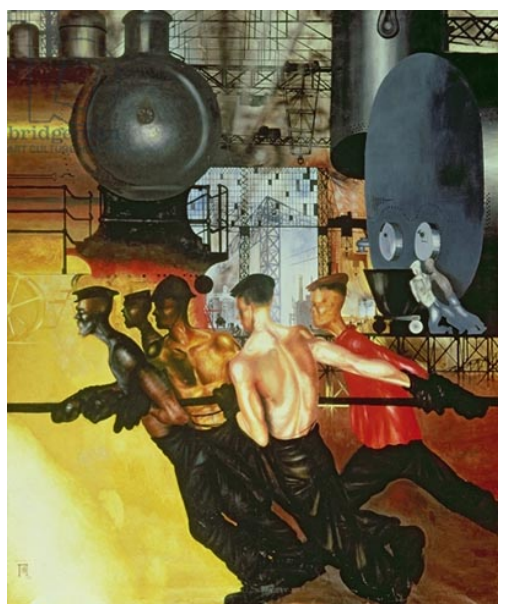

Figure 5. Yuri Pimenov, Let there be heavy industry!oil on canvas, 1927. 
Lenin addresses the public in the tribune. He is holding hat in his right hand and the collar of his jacket in his left. The Soviet Union flag with a hammer and sickle is flying in front of the tribune. The five-pointed star stands out on the flag. The vibrant and dark colors used in the foreground and the light color of the background create depth.

Aleksandr Deyneyka, who lived in Russia between 1899 and 1969, produced figurative works in the style of Russian modernism (Юсупова \& Копелович, 2018, s. 340). He glorified Socialism in 1929 and 1930 with his work "The Defense of Petrograd" (Figure 7). In the work, the Russian navy soldiers defending the city of Sevastopol are not afraid and bravely protect their homeland. This work depicts the heroic story (Aliyeva Onen, 2019: p. 45).

After 1930, works praising the proletariat in the Soviet Union began to be produced in all countries included in the union. In the period when Socialist Realism was dominant, works on portraits, landscapes, still life and history were included in painting along with figurative composition. Soviet Union artists reflected the beautiful in their works. In 1932, the Union of Painters of the Soviet Socialist Republic (UPSSR) was established to unite the artists of the Soviet Union under a single roof. With the Union of Painters of the Soviet Socialist Republic, the influence and development of Social Realism in art was being followed. This institution has constantly organized exhibitions, provided state orders, artistic materials and workshops to support artists who produced artworks

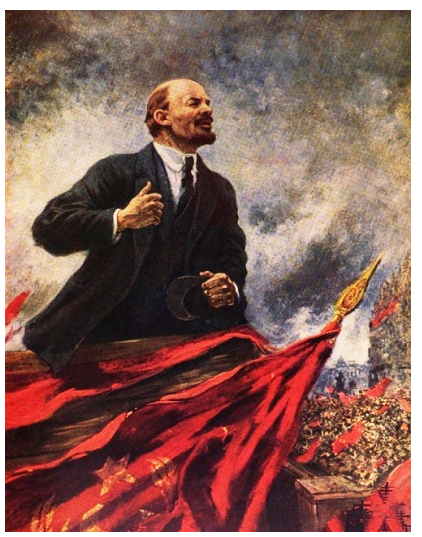

Figure 6. Aleksandr Mikhailovich Gerasimov. Lenin in Tribune, oil on canvas, 1929-1930.

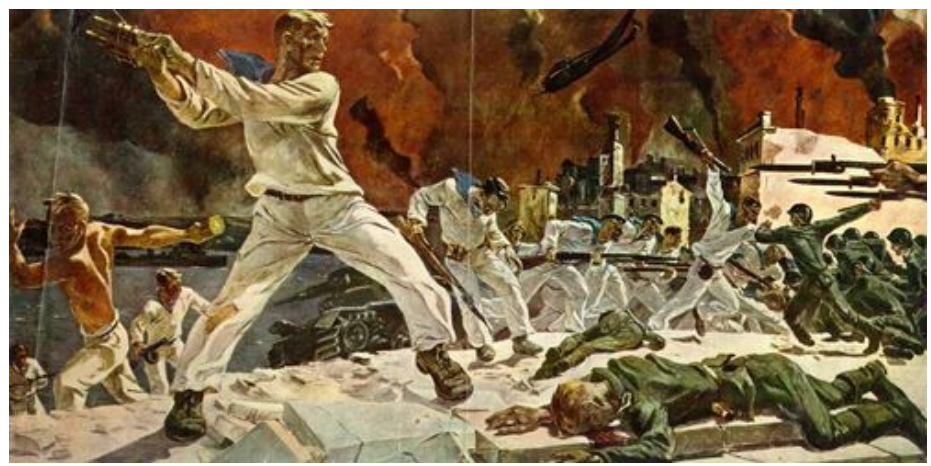

Figure 7. Aleksandr Deyneyka, Defense of the Petrograde, Oil on canvas. 1930. 
with the understanding of Socialism. Art events were organized by the Union of Painters of the Soviet Socialist Republic, specific to the fifteenth anniversary of the art of the Soviet Union. Together with the UPSSR, the Soviet Writers Union and many state institutions operated under the influence of Social Realism (Akpinar, 2014: p. 10).

Along with the works produced in the style of Social Realism, which was the dominant view in the art of the Soviet Union, the Worker and Farmer statue created by the sculptor Mukhina in 1935-1937 took place. In this period, the portrait type developed in the field of sculpture in Soviet art. However, monumental sculptures such as "Worker and Farmer" statues constituted the majority (Figure 8). Mukhina was born in Latvia in 1889 to a Russian family. Vera Mukhina is the first Soviet woman sculptor. She included the understanding of femininity and masculinity in her works. In her large-scale works, she combines the strength, flexibility of the figures, the expression of feelings with soft lines. The Worker and Farmer statue, which has all these features, carries the "dynamism of the great industrial age” (Джанджугазова, 2013: p. 6). The working class was represented with this work. There are male with sickle and female figures holding a hammer in one hand. Social equality is symbolized with these symbols. "In this framework, the victory of the workers and peasants against the Tsarist rule is represented by the statue" (Satır, 2018: p. 577). In this work, the artist refers to the development of Socialism with the understanding of unity and togetherness. The Worker and Farmer statue was exhibited in the Paris fair in 1937 and attracted a lot of attention here. This statue has been accepted as the symbol of Socialism.

With the entry of the Soviet Union into the Second World War, the slogan "Everything is for victory, Everything is for the military" has been memorized. The works of propaganda character produced under the influence of this slogan directed the people to fight, protect the homeland and contribute to the military. During this period, issues such as war and victory were included, a high spirit was formed in the people with the effect of propaganda, and a maximum contribution was made to the war. Child power has also been used with adults in

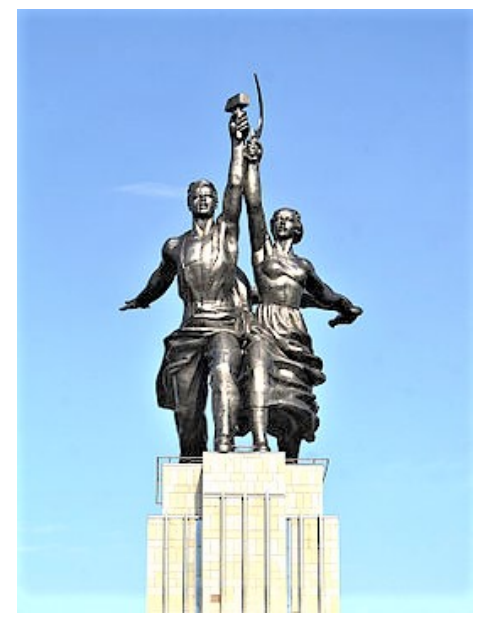

Figure 8. Vera Muhina, Worker and Farmer statue, stainless steel, 36 meters long, 1936. 
industry and agriculture. Soviet painting artists Serov's "Lenin Announces Soviet Power", Denisov's "Citizens of the Soviet Union send your warm clothes to the gold army soldiers fighting with vices", Koretsky's "Be the Hero", Bojko's "Victory Banner", Yoganson's "Celebrate Victory" and Vatolina Nina and Nikolai Denisov's "Speech", Babayev's "Battle Veteran" It is one of the revolutionary works made. With these works, it was preferred that the state and power be supported by the people (Efendi, 2007: p. 255). Based on this, poster style works constituted the majority. As a matter of fact, the poster named "Don't Speak" by Vatolina Nina and Nikolay Denisov in 1941 has the artistic characteristics of the period (Figure 9). This poster is a warning against any acts of espionage and sabotage that may arise from wartime German spies. At the same time, the warning feature of red color was used on the banner. The working-class woman, with her bright red headscarf, commands a hush with a solemn gaze and a finger on her lips. The words of the poet Marshak, "We are resting nowadays, be careful and the distance between babbling, gossip and betrayal is short" appeared in the upper right corner of the poster. The word "don't speak" is written under the work in large font and red (Артбижный \& Свердловский, 2015).

\subsection{Neorealism}

The Socialist Realism style in post-war Soviet art remained effective until the second half of the $50 \mathrm{~s}$. Although it was the period when the Social Realism style escalated in the $60 \mathrm{~s}$ of the Soviet Union, a period of softening started with the death of Stalin. In 1962, an artistic event specific to the $30^{\text {th }}$ anniversary celebrations of the Russian Painters Union was held in Moscow, the capital of Russia. Avant-garde painters took part in the exhibition held in the Manege square with their works. The head of the Politburo Khrushchev undertook the opening task of the exhibition. In this exhibition, which featured avant-garde works, Khrushchev strongly stated that the understanding of Western art of the period was nonsense. After this event, which resonated outside the Soviet Union, interest in Elye Belyütin's art increased (Yıldırım, 2020: p. 447).

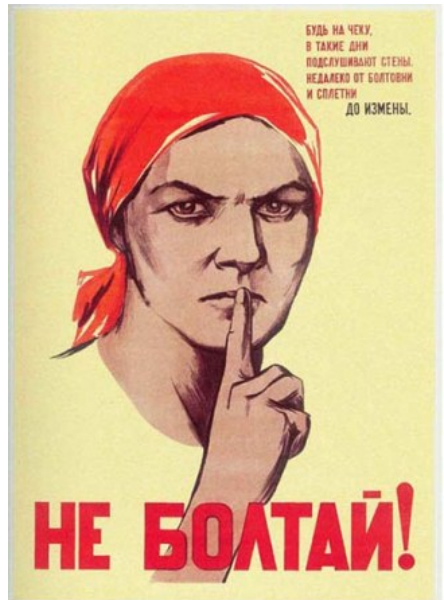

Figure 9. Vatolina Nina and Nikolay Denisov, Don't speak, Poster, $60 \times 44.1941$. 
Elye Belyütin was born in 1925 in the Soviet Union. He is a graduate of the Moscow State Academy of Fine Arts. The artist is the founder of the New Realism art workshop. He has worked with over 3000 students here. The avant-garde artist presented his painting named The Village girl in 1960 (Figure 10). In the abstract work, a mass of paint consisting of pure colors was placed on the blue background. Here the colors are created with random brush strokes. Many brush strokes are structured vertically. There are forms consisting of circular elements in the work. White, red, black, yellow and brown were used in the work.

\subsection{Hard Realism}

During this period, works with national and traditional views emerged in Soviet Union art. Tahir Salahov, an Azerbaijani and Russian painting artist, introduced the style of Hard realism. However, in the works produced with different expressions during the Soviet period, subjects were included in line with the regime's recommendations. "Tahir Salahov was the first artist to demonstrate Hard realism in Azerbaijanian and Russian painting. The name of this style is hard realism due to the fact that it did not meet the painting criteria of the period. This new language of expression emerged in the Khrushchev era after Stalin's death against the art proposal of Social Realism, the politics of the regime" (Onen, 2021: p. 8).

The artist was born in 1928 in Azerbaijan. He completed his art education at the Moscow State Academy of Fine Arts. In 1967, he put forward his work named Absheron's women (Figure 11). Women dealing with the difficulties of daily life are depicted. In this work, which is presented with an artistic expression, women who are waiting by looking at different directions are depicted. There are five women and two children on the Caspian coast. Women are depicted as tired and weary. The life of the society is reflected in an expressionist understanding with this work (Хапаева, 2016).

Brezhnev came to power after Khrushchev. The years 1970-80 have been described as a period of stagnation. As a reflection of the recession period, stagnation was experienced in the field of art. "During this period, artists started to produce works with a new style of expression. Along with these, the Photorealism style started to spread in the late 70's. The artist named Aleksandr Shilov,

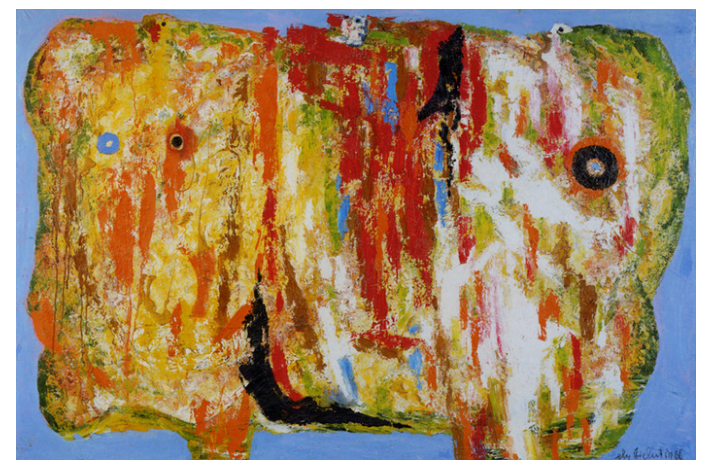

Figure 10. Elye Belyutin. Village girl. Oil painting, canvas, 1960. 
who adopted this style, was popular with the Soviet audience (Aliyeva Onen, 2019: p. 51). The stagnation has affected the economic, political and cultural fields along with the arts. Nevertheless, contemporary, innovative views began to take place in art. Although the government tries to protect the effectiveness of the Social Realism understanding in art, contemporary views started to take place as a reaction to prohibitions and obstacles. The government was obliged to reopen the exhibition in Moscow in 1974, following the negative reaction of the public against the distribution of the works of 24 avant-garde painters.

New approaches to art have emerged in the last decade of the Soviet Union. Artists in Soviet countries started to produce works reflecting national views. Cevat Mircavadov is one of the artists who create works based on traditional values. This artist was born in 1923 in Baku, Azerbaijan (Nar gallery, 2015). Mircavadov made his work titled Wedding in 1980 (Figure 12). Although there were reactions against Mircavadov's art during the Soviet period, he benefited from mythological and folk art. In this work, mythological characters in Azerbaijani folk art are depicted. Wedding culture reflecting traditional values is conveyed in the work. In the picture, there is a figure shooting upwards with a gun. In the foreground is the donkey, which was used as a vehicle in the villages in ancient times. Some figures in the work are depicted by joining their hands, while others are standing. Blue and red color tones are dominant in the work.

During these years, with many innovations in Soviet art, groups supporting new art movements were established. Groups contributed to the development of

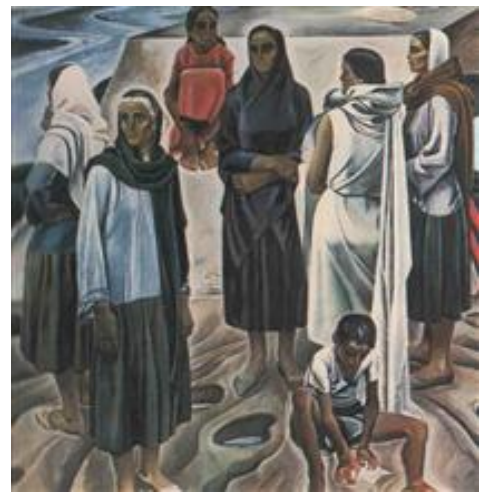

Figure 11. Tahir Salahov. Absheron's Women, Oil on canvas, 1967.

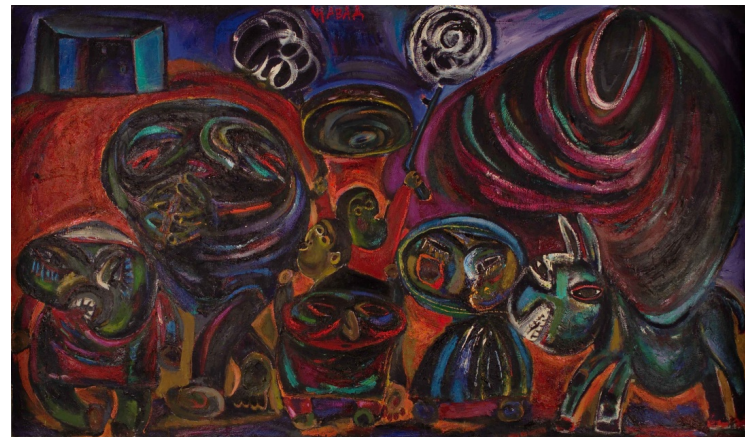

Figure 12. Cavad Mircavadov. Wedding. $156 \times 264.1980$. 
contemporary arts. New understanding of art for Soviet artists has been supported by European curators and institutions. Now, works with original expression style started to be produced in art. The view "Art is for art" has been adopted in certain segments. The 1980s, the wrong decisions taken in the Soviet Union accelerated the dissolution of the union. Thus, with the removal of the Iron Curtain after the rule of Mikhail Gorbachev, modern and original expressions and innovations began to dominate in art. With the collapse of the Soviet regime, there were developments in social, artistic and cultural fields.

\section{Conclusion}

As a result of the events that took place in Russia in 1917, the October revolution took place with the support of the Bolshevik movement and the working class. After the revolution, the Soviet Union was established. In the early years of the Soviet Union, based on the revolutionary movement, innovative views were adopted; Styles such as Suprematism and Constructivism have emerged. Artists have created works with an innovative and revolutionary understanding and developments have been made in artistic, cultural and social fields. However, it is seen that artists such as Vladimir Tatlin, El Lissitzky, Gustav Klutsist also produced works with propaganda tendencies.

In the Soviet Party Congress in 1932, the concept of social realism was put forward and with the support of the government, this understanding was accepted as the dominant view in all areas. After that, the artists who did not adopt the Socialist view were excluded by the regime. For this reason, many artists left the country.

It has been seen that the works produced with a socialist understanding include homeland, war and historical issues. The plans of the totalitarian regime to build Soviet people by penetrating all segments of society reflected the communist ideology. With the emergence of the Second World War, the Soviet understanding of realism rose. During the Second World War period, many works have been produced in order to create a heightened spirit in people on this understanding. Poster style works constituted the majority. The dominant understanding of the Social Realism style in Soviet art caused the development of art at a uniform level.

In 1960, with the softening period, New realism and Hard realism styles emerged in art. In the works produced in the style of Hard realism, there is an expression of the realities of the society. During these years, the artists produced works with a Socialist understanding based on national and traditional values.

The period of Stagnation in 1970 showed its effect in all fields including art. Then, with Gorbachev's coming to power, the collapse of the Soviet Union began in the 1980s. In this process, the understanding of Socialism left its place to contemporary views. Artists started to produce works with new approaches. "Socialist in meaning, national in form" has taken place in art. "In the early 1990s, Russia and many other post-communist countries faced stagnation and crisis of 
an unprecedented scale since the Second World War" (Pyzik, 2014).

The prevalence of socialist understanding in many areas for a long time has created difficulties in the inadequacy of the artistic accumulation of the society and in the acceptance and perception of new artistic conceptions.

\section{Conflicts of Interest}

The author declares no conflicts of interest regarding the publication of this paper.

\section{References}

Akpinar, S. (2014). The Approach of Social Realism to the Relationship between Literature and Politics in the Triangle of Society-Art and Ideology. International Journal of Social Studies, 7, 30.

Aliyev, R. (2007). Azerbaijani Cinema in the Soviet Era and Post-Independence: An Ideological Perspective. Master Thesis, Ankara: Ankara University Institute of Social Sciences, Department of Radio Television Cinema.

Aliyeva Önen, L. (2019). Approaches Emerging in Azerbaijani Painting Art after 1990 and Their Reflections on Art Education. Ph.D. Thesis, Atakum: Ondokuz Mayis University, Department of Fine Arts Education.

Antmen, A. (2010). 20th Century Western Art Movements. Istanbul: Sel Publishing.

Avşar Karabaş, P., \& Damar, M. B. (2016). Avant-Garde Artist Kazimir Malevich and Suprematism. Idil, 5, 101-114. https://doi.org/10.7816/idil-05-20-08

Bannister, F. (2012). Revolutions in Time, Space and Art: Russian Constructivism.

Barut, E., Odacioğlu, C. M., \& Köktürk, Ş. (2016). The Effect of Thought Movements on Literary Works in the Union of Soviet Socialist Republics (USSR): Translation Censorship in the USSR. Journal of History School (JOHS), 9, 459-479.

Bozdağ, L. (2015). Looking Again Contemporary Art and Political Transformation "The Aesthetic State of Politics". Journal of Education Science Society, 13, 94-127.

Cebrailoğlu, O. (2005). Miniature Effects in Contemporary Azerbaijan Painting. Unpublished Ph.D. Thesis, Konya: Selchuk University Institute of Social Sciences.

Çöklü, A. G. (2014). The Utopian Aspect of Constructivism. Master Thesis, Ankara.

Çolak, M. (2020). A Revolutionary Monument: The Tower of Dessert. Academy of Science and Enlightenment. Matter, Dialectics and Society, 3, 31-36.

Efendi, R. (2007). Azerbaijani Art. Baku: East-West Publishing.

Efendiyeva, N. T. (2010). XX Century Russian Culture: Soviet Culture. In M. Manafova, N. T. Efendiyeva, \& S. A. Şahhüseynova, (Eds.), Cultural, History and Theory (pp. 339-341).

Haciyev, C. X., \& Dadaşzadə, M. A. (1969). Soviet Literature. Baku: Maarif.

Hudaynazarov, B. (2003). The Dissolution Process of the Soviet Union (N. Khrushchev and M.S. Gorbachev Times). Master's Thesis, İstanbul: Istanbul University Institute of Social Sciences, Department of International Relations.

Kenez, P. (2003). Soviet Cinema of the Stalin Era, World Cinema (A. Fethi, Trans.). Istanbul: Kabalc1.

Köktürk (2017). Leninden Staline Russian Revolution 1917-1929. History Critique, 3, 59-64.

Nar Gallery (2015). Cavad Mircavadov. 
http://nar-gallery.com/az/artist/javad-mirjavadov/\#

Onen, L. (2021). Investigation of Azerbaijani and Russian Painting Artist Tahir Salahov's Works Created in the Style of Hard Realism, a New Form of Expression.

Patterson, J. (1999). International Azerbaijan Magazine.

Pyzik, A. (2014). Get Real: Why Socialist Realist Painting Deserves Another Look (Translate Ayşe Boren). Calvert Journal.

https://www.e-skop.com/skopbulten/sovyet-sosyalist-realizmine-yeniden-bakmak/4768

Roy, O. (2000). New Central Asia or the Production of Nations (Mehmet Moral, Trans.). Istanbul: Metis Publications.

Sabancal1, S. (2006). Investigation of the Place and Importance of Line in Azerbaijani Art in Terms of Painting Education. Master Thesis, Konya: Selchuk University Institute of Social Sciences.

Satır, M. E. (2018). Soviet Monumental Propaganda in the Context of the Relationship between Ideology and Art. Manas Journal of Social Research, 7, 566-583.

Şimşek, A. (2007). Art and Power, Art History and Art Movements in the Process of Political History (3rd ed.). Ankara: Kangaroo Publications.

Sözen, M. (2001). Art Concepts and Terms Dictionary (6th ed.). Istanbul: Remzi Publishing House.

Tağızade, L. (2006). Social Realism: Its Origin, Formation Process and Concept, Ankara University. Journal of Modern Turkish Studies, 3, 7-24.

Uyanı, O. (2012). Effects of Rodchenko and El Lissitzky on Graphic Art. Master Thesis, Istanbul: Işık University Institute of Social Sciences.

Uygur, E. (2005). Emergence of the Concept of Socialist Realism. Social Studies Journal-Turkish Journal of Social Research, 9, 23-30.

Yildırım, S. (2020). "Formations, Reformatıons, Deformatıons" Tracing Architectural History of the Communal Room in the Works of Soviet Nonconformist Artists: 1975-1991. The Degree of Doctor of Philosophy in Department of Architectural History, School of Social Sciences of Middle East Technical University.

Артбижный суд, Свердловский области (2015). The History of the War in a Propaganda Poster (1941-45). Information Courtesy of the Staff of the Regional Court. https://ekaterinburg.arbitr.ru/node/17386

Джанджугазова, Е. А. (2013). Vera Mukhina- “The First Lady of Soviet Sculpture”(pp. 5-10). Modern Problems of Service and Tourism, Collection of Histories, No. 4.

Иньшаков, А. (2018). About the Future in the Work of El Lissitzky. Art History, 18, 180-219.

Лаптева, Л. (2013). Kind Talent Master. Yuri Pimenov. To the 110th Anniversary of the Birth. Moscow: Leonid Shishkin Gallery.

Мордвинова, Т. Ю. (2017). Lissitzky's Creativity-Print Artist in the Context of European Artistic Thought (Towards the History of Modular Layout). Bulletin of Vgu. Series: Philology. Journalism, 769, 142-145.

Пунин, Н. (1994). About Tatlin. Archive of the Russian Avant-Garde (Compiled by I. N. Punin \& I. V. I. Rakitin). Moscow: Itepatopnth-X Economic Agency "RA".

Хан-Магомедов, С. О. (1975). Masters of Soviet Architecture on Architecture. Volume II, “Art”. Moscow.

Хапаева, Л. (2016). Tair Salakhov Gallery. https://papahastories.ru/tair-salahov

Юсупова, Р. Х., \& Копелович, Н. П. (2018). Poster Laconicism and Monumentality of the Painting Style A.A. Deineki. Urfa (pp. 339-344). 